\title{
Development of Solar operated Maize Sheller
}

\author{
Bhupendra Ghritalahre* and M. Quasim \\ FMPE, SVCAET\&RS, IGKV, Raipur (C.G.), India \\ *Corresponding author
}

\begin{tabular}{l} 
Ke y w o r d s \\
Development, \\
Shelling, Solar \\
Energy, Maize \\
\hline Article Info \\
\hline $\begin{array}{l}\text { Accepted: } \\
\text { 15 May 2020 } \\
\text { Available Online: } \\
\text { 10 June 2020 }\end{array}$ \\
\hline
\end{tabular}

\section{A B S T R A C T}

Maize sheller is the most common shelling machine or device for maize. In the market there is numbers of maize sheller either manually operated or power operated is available but research has been going on to design a simple and productive maize sheller. The developed solar maize sheller is solar powered to suit the maize farmers of remote area where electricity is not available. The sheller consist different component such as Shelling assembly, DC motor, Solar panel, Battery etc. the overall dimension of developed solar maize sheller is $1055 \mathrm{~mm} \mathrm{X} 645 \mathrm{~mm}$ X $450 \mathrm{~mm}$. the solar panel of capacity 40 watt is use as source of energy for dc motor of 250 watt. In additional battery of capacity 168 watt is provided. The output capacity of the developed sheller is $174.33 \mathrm{~kg} / \mathrm{h}$.

\section{Introduction}

Maize (Zea mays L) is one of the most versatile emerging crops having wider adaptability under varied agro-climatic conditions. Maize is the fast-growing crop in India and second preferred crop after paddy in some state. The processing of maize includes three major steps namely harvesting, shelling and milling in which all the step have their own importance. Harvesting is the plucking of cob from the plant and then the plant is harvested for animal feeding. After plucking the maize cob from the plant, maize cob is dehusked manually and then dried by using sun rays to reduce the moisture content. Shelling is the process of removing maize kernel from cobs. There are different types of shelling equipment and each type has different scales of conditions and production. Maize shelling manually is a very exhausting and time-consuming task and the palm and fingers of farm women injured during maize shelling which decreases the efficiency of farm women. The power maize shelling need high capital investment and cannot use in remote areas. So it is need to develop a sheller for marginal farmer of remote area which 
overcome the problem arising during maize shelling.

\section{Materials and Methods}

\section{Working Principle of solar maize sheller}

The machine is work on the principle of photovoltaic effect. The developed solar maize sheller use solar panel for energy. Solar energy is converted to DC current by the solar panel and transfer the current to the battery and motor. In the machine one on/off switch is provided to control the flow of current. Arrangement is in such a way that solar panel and battery can simultaneously use for operating machine and also individually. In non-working time solar panel charge the battery used. In shelling cylinder the iron chain with iron bar at the end is provided which rotate with rotating shaft. The rotating motion of shaft is received from DC motor and continuously strike the maize cob. The maize kernel is perfectly dried and start detaching from cobs.

\section{Design consideration}

The design of machine include the calculation of power required, length of chain and calculation of speed ratio etc. the main component of machine is chain and sprocket for drive mechanism and electrical arrangement to suit the working condition. Sieve of suitable opening is use to remove the maize kernel through it.

Performance of the developed machine is evaluated using the different maize variety of maize crop and also for different rate of feeding. The performance of sheller is evaluated on the use of mathematical formula (BIS standard). The result obtain from evaluation show that the capacity of sheller is $174.33 \mathrm{~kg} / \mathrm{h}$ with shelling cost $0.266 \mathrm{Rs} / \mathrm{kg}$. By analysing the result developed machine is found satisfactory.

\section{Constructional detail of component and material used}

The developed maize sheller consists following main parts:

\section{Machine frame}

The machine frame is rigid base of the machine. Frame carries an entire load of shelling assembly. The frame supports the entire component and gives strength to the machine while working. The M.S. angular bar of size 40 X40 mm and having a thickness of $5 \mathrm{~mm}$ was used for manufacturing. The bottom side of the frame is also rigidly fixed with the angular bar to give extra support to the frame. The machine frame is fabricated with overall dimension $645 \mathrm{~mm}$ length, 765 $\mathrm{mm}$ height and $450 \mathrm{~mm}$ width.

\section{Shelling assembly}

The shelling assembly consist shelling cylinder (inner cylinder), sieve attached to the bottom of the cylinder and outer cover. The shelling cylinder is made up of an MS sheet having thickness $7 \mathrm{~mm}$.the shaft is attached with the help of coupler and coupler is fixed in the frame. The shaft inside the cylinder is provided with the iron chain and welded at a specific distance. The length of the iron chain was $160 \mathrm{~mm}$ and the distance between two chains was $90 \mathrm{~mm}$. The length of the threshing cylinder is $490 \mathrm{~mm}$ and the diameter is $390 \mathrm{~mm}$. the sieve is placed at a distance $350 \mathrm{~mm}$ from the top of the cylinder and $40 \mathrm{~mm}$ from the bottom of the cylinder.

\section{Shaft}

The shaft is a solid rod of mild steel material. The shaft bear the force and torque generated. The shaft is equipped with an iron chain and at the end of the chain, small solid bar is welded. The length of the shaft is $750 \mathrm{~mm}$ and the diameter of the shaft is $21 \mathrm{~mm}$. 


\section{Sieve}

Sieve is a perforated GI sheet. The perforation on the sieve is $10 \mathrm{~mm}$. The sieve is attached to the bottom of the shelling assembly to allow the falling of shelled maize kernel and retain the cob pith. The sieve is fitted at a distance of $40 \mathrm{~mm}$ from the bottom of the cylinder. The sieve dimension is $470 \mathrm{~mm} \times 210 \mathrm{~mm}$.

\section{C. motor}

The motor is fixed at a distance of $340 \mathrm{~mm}$ from the top of the frame and $355 \mathrm{~mm}$ from the bottom of the frame. Power is transmitted to shaft by using the chain and sprocket. The actual speed of the motor is $3000 \mathrm{rpm}$ which is reduced to $300 \mathrm{rpm}$ by gear arrangement by the manufacturer. The diameter of the shaft is $8 \mathrm{~mm}$. the power required to shell the maize is found 130 watt and is calculated using following formula

Total power required to shell the maize (Kumar et al., 2016)

$\mathrm{P}_{\mathrm{T}}=\mathrm{P}_{\text {ironchain }}+\mathrm{P}_{\mathrm{S}}+$

$\mathrm{P}_{\text {shelling }}$

$\mathrm{P}_{\text {ironchain }}=$ Power in inner iron chain

$\mathrm{P}_{\text {shaft }} \quad=\quad$ Power in shaft

$\mathrm{P}_{\text {shelling }}=$ Power utilized by shelling (seed)

\section{Chain and sprocket}

Chain and sprocket are used for power transmission. Two sprockets are used, one is attached with the motor shaft and another is machine shaft. The power from the motor shaft and sprocket is delivered to the sprocket and shaft of the machine through the chain. In driver sprocket, there are 21 teeth having pitch circle diameter $12.7 \mathrm{~mm}$ and 17 teeth for driven sprocket having pitch circle $12.7 \mathrm{~mm}$. The speed ratio of diver and driven sprocket is 2.13. The length of the chain is $960 \mathrm{~mm}$ and the number of the link on the chain is 72 . The above parameters are calculated using following formula.

The size of the sprocket is measured on the basis of teeth and the revaluation of the sprocket. (Sharma 2013)

$\mathrm{RPM}_{1} \times \mathrm{N}_{1}=\mathrm{RPM}_{2} \times \mathrm{N}_{2}$

Where,

$\mathrm{RPM}_{1}=$ No. of revolution of driver sprocket

$\mathrm{RPM}_{2}=\quad$ No. of revolution of the driven sprocket

$\mathrm{N}_{1} \quad=\quad$ Number of teeth on driver sprocket

$\mathrm{N}_{2} \quad=\quad$ Number of teeth on driven sprocket

Chain Length can be determined by using the following formula according to Khurmi et al., (2005).

$\mathrm{L}=\frac{\mathrm{p}}{2}\left(\mathrm{~T}_{1}+\mathrm{T}_{2}\right)+2 \mathrm{x}+\frac{\left\{\frac{\mathrm{p}}{\mathrm{g}} \operatorname{cosec}\left(\frac{180^{0}}{\mathrm{~T}_{1}}\right)-\frac{\mathrm{p}}{\mathrm{z}} \operatorname{cosec}\left(\frac{180^{0}}{\mathrm{~T}_{2}}\right)\right\}^{2}}{\mathrm{x}}$

Where,

$\mathrm{p}=$ pitch of chain

$T_{2}=$ No. of teeth in driven sprocket

$T_{1}=$ No. of teeth in driver sprocket

$\mathrm{x}=$ distance between the shaft

\section{Battery}

The battery is shown in fig 3.22. The battery is a device used to convert the chemical energy into electrical energy.it is used to run the motor. The dry battery of 12 volts and 7 ah is used.

\section{Solar panel}

A solar panel is a device that is the best source of direct current. The solar panel is an arrangement of the solar cell. The solar cell is 
made up of silicon and work based on photovoltaic effect it produces energy with the help of sunlight.it uses photons of sunlight to convert it into energy. The solar panel used is 12 volt. 2 unit of 40 watts solar panel are used.

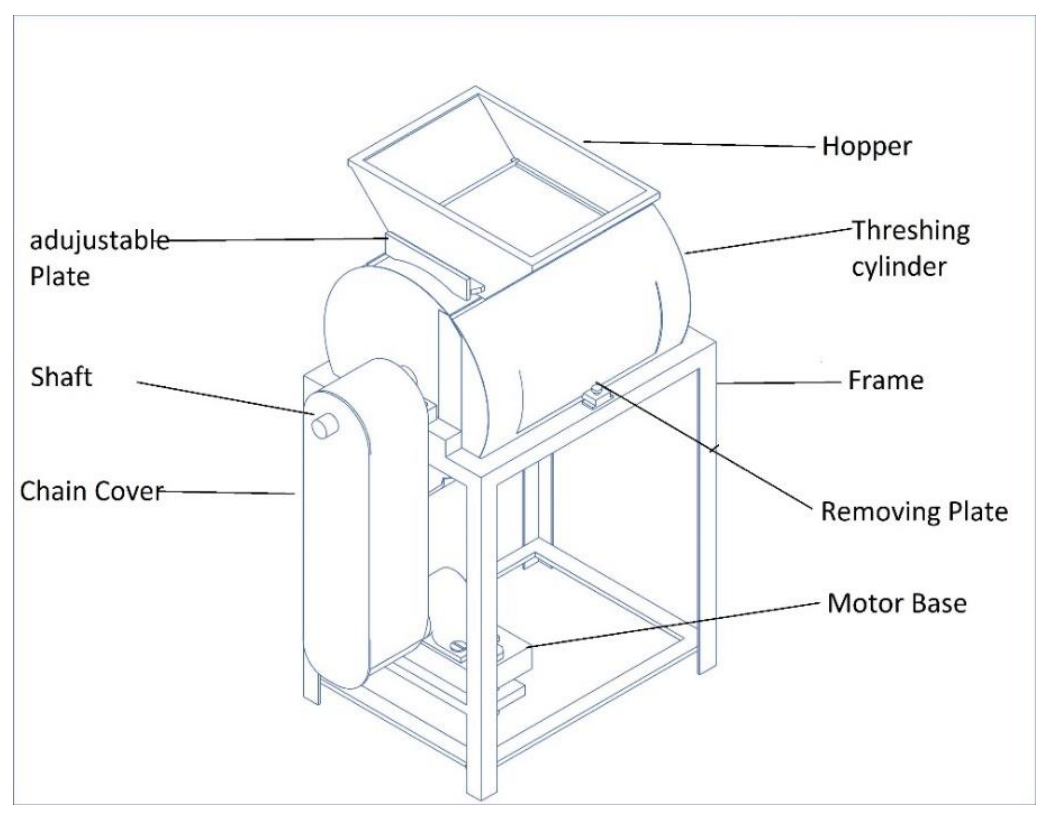

Fig.1 Component of sheller

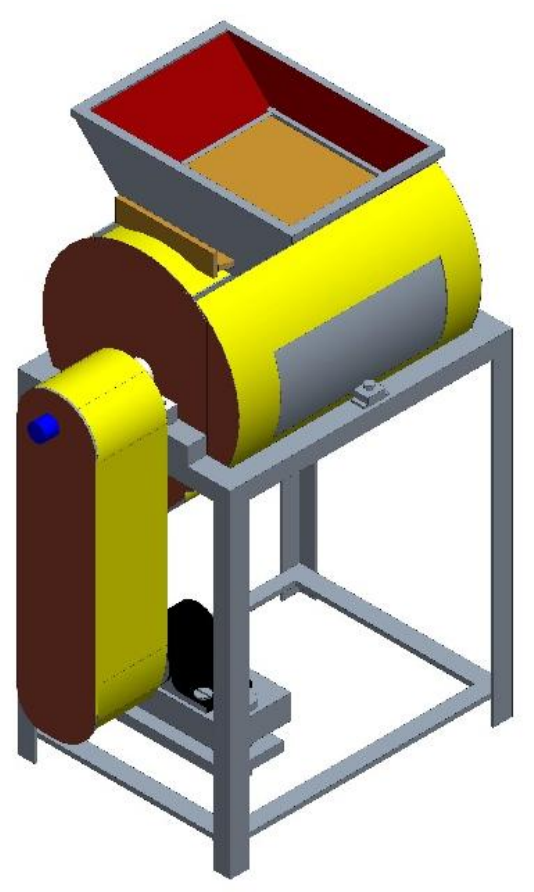

Fig.2 3D view of sheller 

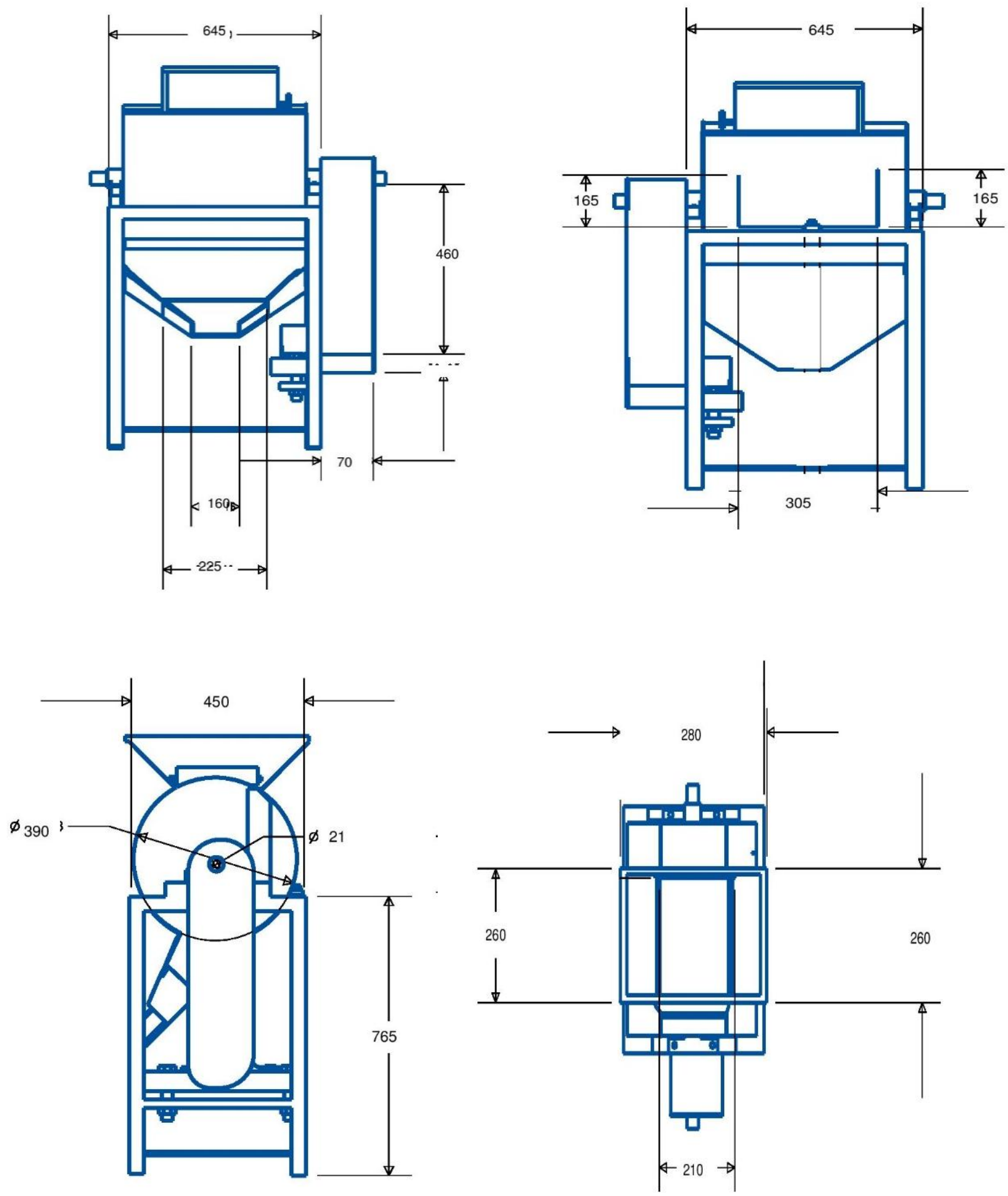

Fig.3 Schematic diagram of machine

\section{References}

Amare, D., Endelaw, W., Yayu, N., Endeblihatu, A., Biweta, W., Tefera, A. and Tekeste, S. 2017. Evaluation and demonstration of maize shellers for small-scale farmers. MOJ Applied Bionics and Biomechanics, 1(3):93-98. Anonymous 1986. Small-scale maize milling, UNIDO/ILO Technical Memorandum 
No.6, January p.51, 53.

CIAE, Bhopal. 2005. Drudgery reducing technologies for women in agriculture. http:// www.ciae.nic.in.

Joshi Hem Chandra, 1981. Design and selection of thresher parameters and components. Agril. Mechanization in Asia, Africa, Latin America,12(2): 6170.

Khurmi, R.S. and Gupta, J.K. 2005. A textbook of machine design. $14^{\text {th }}$ edition, S. Chand and Co. Ltd. New Delhi, p.375-376.

Sahu, D. K., Sahu, O., Sahu, P. K., Gour, R and Sahu, Y. K. 2016. Design, development and testing of groundnut decorticator. B. Tech Thesis, Indira Gandhi Krishi Vishwavidyala, Raipur, p. 30.

Sharma, D. N. and Mukesh, S. 2013. Farm machinery design principles and problems. $3^{\text {rd }}$ Edition, Jain brothers New Delhi- 110005: 56-57.

CIAE, Bhopal. 2005. Drudgery reducing technologies for women in agriculture. http:// www.ciae.nic.in.

\section{How to cite this article:}

Bhupendra Ghritalahre and Quasim, M. 2020. Development of Solar operated Maize Sheller. Int.J.Curr.Microbiol.App.Sci. 9(06): 738-743. doi: https://doi.org/10.20546/ijcmas.2020.906.094 